\title{
Compound 48/80, a histamine-depleting agent, blocks the protective effect of morphine against electroconvulsive shock in mice
}

\section{C.H. Karadag, D. Dokmeci, \\ T. Dost, A. Ulugol \\ and I. Dokmeci}

\author{
Department of Pharmacology, Faculty of Medicine, \\ Trakya U niversity, Edirne, Turkey
}

\section{Correspondence \\ C.H. Karadag \\ Farmakoloji Anabilim Dali \\ Tip Fakultesi \\ Trakya U niversitesi \\ 22030 Edirne \\ Turkey \\ Fax: + 90-284-235-2476 \\ E-mail: karadag@ turk.net}

Received August 3, 1999

Accepted January 12, 2000

\section{Abstract}

We have shown that morphine has an anticonvulsive effect against maximal electroconvulsive shock (MES) in mice, and this effect is antagonized by histamine $\mathrm{H}_{1}$-receptor antagonists. Brain histamine is localized both in neurons and in mast cells, and morphine is known to enhance the turnover of neuronal histamine and to release histamine from mast cells. In the present experiments, compound $48 / 80$ was injected chronically $(0.5 \mathrm{mg} / \mathrm{kg}$ on day $1,1 \mathrm{mg} / \mathrm{kg}$ on day $2,2 \mathrm{mg} / \mathrm{kg}$ on day $3,3 \mathrm{mg} / \mathrm{kg}$ on day 4 , and $4 \mathrm{mg} / \mathrm{kg}$ on day 5 , twice daily, ip) to deplete mast cell contents. Morphine (0.001-10 mg/kg, ip; $\mathrm{N}=20$ ) produced a dose-dependent anticonvulsive effect against MES seizure in mice with non-depleted mast cells, whereas it did not exert any anticonvulsive effect in mice with depleted mast cells. These results indicate that morphine produces its anticonvulsive effect against maximal electroconvulsive shock in mice by liberating histamine from mast cells.

It has been reported that some of the central effects of morphine are mediated by the histaminergic system (1-4). Brain histamine is localized in both neurons and mast cells (5-9). Acute morphine treatment is known to increase the turnover of neuronal histamine (10) and to release histamine from mast cells in peripheral tissues $(11,12)$. As a result, there are two different possible ways for morphine to activate central histaminergic mechanisms. In a previous study, we showed that morphine has an anticonvulsive effect against maximal electroconvulsive shock (MES) in mice, and this effect was antagonized by histamine $\mathrm{H}_{1}$-receptor an- tagonists (4).

In the present study we determined whether mast cell histamine content plays a major role in the anticonvulsive effect of morphine in mice.

Male albino mice (Eczacibasi-Turkey) weighing 25-30 g were used. The animals were housed at constant temperature (22 $\pm 1^{\circ} \mathrm{C}$ ), with food and water ad libitum, on a 12-h light/dark cycle (lights on at 6:00 a.m., and off at 6:00 p.m.).

The experiments were approved by the "Center of Laboratory Animals-Animal Care Ethics Committee" of our institution.

Maximal electroshock seizures were in- 
duced through ear clip electrodes by a current generator (Ugo Basile, ECT Unit, 7801). The mice were stimulated with $50 \mathrm{~mA}, 0.4$ ms pulse width, 0.2 -s duration, $60-\mathrm{Hz}$ square wave current. This current, which was calculated in a previous study (4), produces maximal convulsive seizure in half of the animals $\left(\mathrm{MES}_{50}\right)$. Tonic hind-limb extension (THE) was accepted as maximal electroshock seizure. Mice which did not show THE were considered to be protected from MES.

The experiments were carried out on 12 groups of 20 mice each. All experiments were carried out from 2:00 to 5:00 p.m. The animals were used only once.

Group 1 received vehicle $(0.9 \% \mathrm{NaCl}$ solution, control group), and groups 2-6 received various doses of morphine (0.001-10 $\mathrm{mg} / \mathrm{kg}$, intraperitoneally $(i p)$ ) and were subjected to electroshock $1 \mathrm{~h}$ after the injections.

In groups $7-12$, to deplete mast cell content, compound 48/80 was injected chroni-

Table 1 - Effects of chronic treatment with compound 48/80 on the anticonvulsive effect of morphine against MES.

There were 20 mice in each group.

\begin{tabular}{|c|c|c|}
\hline & $\%$ Seizure & $P$ \\
\hline \multicolumn{3}{|c|}{ Mice with non-depleted mast cells } \\
\hline Vehicle & 55 & \\
\hline Morphine (0.001 mg/kg, ip) & 45 & \\
\hline Morphine $(0.01 \mathrm{mg} / \mathrm{kg}$, ip) & 35 & \\
\hline Morphine $(0.1 \mathrm{mg} / \mathrm{kg}$, ip) & 15 & $P<0.05$ vs vehicle, chi-square test \\
\hline Morphine (1 mg/kg, ip) & 0 & $P<0.001$ vs vehicle, chi-square test \\
\hline M orphine (10 mg/kg, ip) & 0 & $P<0.001$ vs vehicle, chi-square test \\
\hline \multicolumn{3}{|l|}{ Mice with depleted mast cells } \\
\hline Vehicle & 45 & \\
\hline Morphine $(0.001 \mathrm{mg} / \mathrm{kg}$, ip) & 50 & \\
\hline Morphine $(0.01 \mathrm{mg} / \mathrm{kg}$, ip) & 55 & \\
\hline Morphine $(0.1 \mathrm{mg} / \mathrm{kg}$, ip) & 50 & $\begin{array}{l}\mathrm{P}<0.05 \text { vs same dose of morphine alone } \\
\text { in mice with non-depleted mast cells, } \\
\text { chi-square test }\end{array}$ \\
\hline Morphine (1 mg/kg, ip) & 45 & $\begin{array}{l}\mathrm{P}<0.01 \text { vs same dose of morphine alone } \\
\text { in mice with non-depleted mast cells, } \\
\text { Fisher exact test }\end{array}$ \\
\hline Morphine (10 mg/kg, ip) & 40 & $\begin{array}{l}\mathrm{P}<0.01 \text { vs same dose of morphine alone } \\
\text { in mice with non-depleted mast cells, } \\
\text { Fisher exact test }\end{array}$ \\
\hline
\end{tabular}

cally as follows: 1 st day $0.5 \mathrm{mg} / \mathrm{kg}$, 2nd day $1 \mathrm{mg} / \mathrm{kg}$, 3rd day $2 \mathrm{mg} / \mathrm{kg}$, 4 th day $3 \mathrm{mg} / \mathrm{kg}$, and 5 th day $4 \mathrm{mg} / \mathrm{kg}$, ip, twice daily. On the 6th day, group 7 received vehicle (control) and groups 8-12 received morphine (0.001$10 \mathrm{mg} / \mathrm{kg}$, ip) $1 \mathrm{~h}$ before being subjected to electroshock.

Morphine hydrochloride (Haver, Istanbul, Turkey) was diluted from commercial preparations. Compound 48/80 was purchased from Sigma Chemical Co., St. Louis, MO, USA. All chemicals were dissolved in isotonic $\mathrm{NaCl}$ and administered ip in a volume of $0.1 \mathrm{ml} / 10 \mathrm{~g}$ body weight. The control groups received only $0.1 \mathrm{ml} / 10 \mathrm{~g}$ vehicle $i p$.

Comparisons among groups were made by the chi-square test using Yates correction for continuity and the Fisher exact test when indicated.

Morphine produced a dose-dependent anticonvulsive effect against MES (Table 1) and completely protected against MES seizure at the doses of 1 and $10 \mathrm{mg} / \mathrm{kg}(\mathrm{P}<0.001$ $v s$ vehicle, chi-square test).

There was no significant change in MES seizure percentage in mice submitted to mast cell depletion with compound 48/80. Morphine pretreatment did not protect these mast cell-depleted animals from MES (Table 1).

The brain histaminergic system is known to play important roles in some central morphine effects, i.e., morphine-stimulated locomotion (2), morphine antinociception (1), and morphine-induced hypothermia (3). In a previous experiment we showed that morphine has an anticonvulsive effect which is antagonized by histamine $\mathrm{H}_{1}$-receptor antagonists and naloxone (4). Brain histamine is localized in both neurons and mast cells, and there is evidence that mast cell stores of histamine contribute significantly to the overall histamine content of brain (5-7). Acute morphine treatment is known to increase the turnover of neuronal histamine $(10,13)$. Moreover, morphine is also known to release histamine from mast cells in peripheral tissues $(11,12)$ : therefore a morphine action 
on mast cells in the central nervous system should be taken into consideration.

It was reported that elevation of brain histamine concentrations by metoprine inhibits maximal hindleg extension after MES (14), and intracerebroventricular histamine injections or endogenous histamine release in mouse brain exert an anticonvulsive effect against electrically induced convulsions (1517). By using histamine $\mathrm{H}_{1}$ - and $\mathrm{H}_{3}$-receptor agonists and antagonists in electrically and pentylenetetrazole-induced convulsions, Yokoyama et al. (15-17) supported the hypothesis that the central histaminergic system is involved in the inhibition of seizures.

It was also reported that compound 48/ 80 , which is a potent histamine liberator from mast cells, has a protective effect against hypoxia which is mediated by histamine $\mathrm{H}_{1-}$ receptors (18). Intracerebroventricular injection of compound 48/80 produces head and body shakes, paw tremor, grooming, unusual posture, sedation and catatonia, and decreases the histamine concentrations in almost all brain regions and the noradrenaline concentrations in the cerebellum, hypothalamus and medulla oblongata-pons, although the dopamine content was decreased only in the medulla oblongata-pons (6).
Chronic treatment with compound $48 / 80$ did not exert any convulsive or anticonvulsive effect in our study.

It has been shown that mast cell granule contents are depleted by chronic treatment with compound $48 / 80$ (19). In the present experiment, we depleted mast cell histamine contents by chronic treatment with compound 48/80 using a slightly modified dose schedule compared to that used by Jaffery et al. (19).

Morphine has an anticonvulsive effect which is antagonized by histamine $\mathrm{H}_{1}$-receptor antagonists (4). In the present study, morphine showed an anticonvulsive effect against MES in mice with non-depleted mast cells but not in mice with depleted mast cells. These results show that the anticonvulsive effect of morphine is mediated by histamine liberated from brain mast cells in mice. It should also be taken into consideration that mast cells also contain 5-hydroxytryptamine and some other endogenous mediators. Their roles in some central effects of morphine can also be investigated in similar experiments. We conclude that brain mast cell histamine content must be taken into consideration in the central effects of morphine, which are mediated by histaminergic mechanisms.

\section{References}

1. Gogas KR, Hough LB, Eberle NB, Lyon RA, Glick SD, Ward SJ , Young RC \& Parsons ME (1989). A role for histamine and $\mathrm{H}_{2}$-receptors in opioid antinociception. J ournal of Pharmacology and Experimental Therapeutics, 250: 476-484.

2. Mickley GA (1986). Histamine $\mathrm{H}_{2}$ receptors mediate morphine-induced locomotor hyperactivity of the C57BL/6J mouse. Behavioral Neuroscience, 100: 79-84.

3. Ulugol A, Karadag HC, Dokmeci D, Baldik Y \& Dokmeci I (1996). The role of histamine $\mathrm{H}_{1}$-receptors in the thermoregulatory effect of morphine in mice. European J ournal of Pharmacology, 308: 49-52.

4. Karadag $\mathrm{CH}$, Ulugol A, Dokmeci D \& Dokmeci I (1996). The role of histamine $\mathrm{H}_{1}$-receptors in the anticonvulsive effect of morphine against maximal electrocon- vulsive shock in mice. J apanese J ournal of Pharmacology, 71: 109-112.

5. Goldschmidt RC, Hough LB \& Glick SD (1985). Rat brain mast cells: contribution to brain histamine levels. J ournal of Neurochemistry, 44: 1943-1947.

6. Lewis SJ, Quinn MJ, Fennessy MR \& J arrott B (1986). The effects of intracerebroventricular administration of compound $48 / 80$ on behavior and regional brain amine concentrations in the rat. Neuroscience Letters, 65: 84-88.

7. Schwartz J C (1975). Histamine as a transmitter in brain. Life Sciences, 17: 503518.

8. Ibrahim MZM (1974). The mast cells of the mammalian central nervous system. Part I. Morphology, distribution and histochemistry. J oumal of Neurological Sci- ences, 21: 431-478.

9. Dropp JJ (1972). Mast cells in the central nervous system of several rodents. Anatomical Record, 174: 227-238.

10. Nishibori $M$, Oishi $R$, Itoh $Y \&$ Saeki $K$ (1985). Morphine-induced changes in histamine dynamics in mouse brain. J ournal of Neurochemistry, 45: 719-724.

11. Ellis HV, J ohnson AR \& M oran NC (1970). Selective release of histamine from rat mast cells by several drugs. J ournal of Pharmacology and Experimental Therapeutics, 175: 627-631.

12. Rosow CE, Moss J, Philbin DM \& Savarese JJ (1982). Histamine release during morphine and fentanyl anesthesia. Anesthesiology, 56: 93-96.

13. Itoh $Y$, Oishi $R$, Nishibori $M \&$ Saeki $K$ (1988). Involvement of mu receptors in 
the opioid-induced increase in the turnover of mouse brain histamine. J ournal of Pharmacology and Experimental Therapeutics, 244: 1021-1026.

14. Tuomisto L \& Tacke U (1986). Is histamine an anticonvulsive inhibitory transmitter. Neuropharmacology, 25: 955-958.

15. Yokoyama H, Onodera K, linuma K \& Watanabe T (1993). Effect of thioperamide, a histamine $\mathrm{H}_{3}$ receptor antagonist, on electrically induced convulsions in mice. European J ournal of Pharmacology, 234: 129-133.
16. Yokoyama $\mathrm{H}$, Onodera $\mathrm{K}$, linuma $\mathrm{K} \&$ Watanabe T (1994). 2-Thiazolylethylamine, a selective histamine $\mathrm{H}_{1}$ agonist, decreases seizure susceptibility in mice. Pharmacology, Biochemistry and Behavior, 47: 503-507.

17. Yokoyama H, Onodera K, Maeyema K, Sakurai $E$, Leurs $R$, Timmerman $H$ \& Watanabe T (1994). Clobenpropit (VUF9153), a new histamine $\mathrm{H}_{3}$ receptor antagonist, inhibits electrically induced convulsions in mice. European J ournal of Pharmacology, 260: 23-28.
18. Ulugol $A$, Karadag $H$, Dokmeci $D \&$ Dokmeci I (1996). The role of $\mathrm{H}_{1}$ and $\mathrm{H}_{2-}$ receptors in the effect of compound 48/ 80 in the asphyxiation and body temperature of mice. Yonsei Medical J ournal, 37: 97-103.

19. J affery G, Coleman J W, Huntley J \& Bell E (1994). Mast cell recovery following chronic treatment with compound 48/80. International Archives of Allergy and Immunology, 105: 274-280. 